\title{
Blue Velvet: The Rise and Decline of the New Czech Right
}

Manuscript of article for a special issue of the Journal of Communist Studies and Transition Politics on the Right in Post-Communist Central and Eastern Europe

\begin{abstract}
This article analyses the origins, development and comparative success centre-right in the Czech Republic. It focuses principally on the the Civic Democratic Party (ODS) of Václav Klaus, but also discusses a number of smaller Christian Democratic, liberal and anti-communist groupings, insofar as they sought to provide right-wing alternatives to Klaus's party. In comparative terms, the article suggests, the Czech centre-right represents an intermediate case between those of Hungary and Poland. Although Klaus's ODS has always been a large, stable and well institutionalised party, avoiding the fragmentation and instability of the Polish right, the Czech centreright has not achieved the degree of ideological and organisational concentration seen in Hungary. After discussing the evolution and success of Czech centre-right parties between 1991 and 2002, the article reviews a number of factors commonly used to explain party (system) formation in the region in relation to the Czech centreright. These include both structural-historical explanations and 'political' factors such as macro-institutional design, strategies of party formation in the immediate post-transition period, ideological construction and charismatic leadership. The article argues that both the early success and subsequent decline of the Czech right were rooted in a single set of circumstances: 1) the early institutionalisation of ODS as dominant party of the mainstream right and 2) the right's immediate and successful taking up of the mantel of market reform and technocratic modernisation.
\end{abstract}

Dr Seán Hanley

Lecturer in East European Politics

Department of Social Sciences

School of Slavonic and East European Studies

University College London

Senate House

Malet Street

London

WCIE 7HU 


\section{Blue Velvet: \\ The Rise and Decline of the New Czech Right ${ }^{1}$ \\ Seán Hanley*}

\section{Introduction}

This paper seeks to give an analytical overview of the origins, development and comparative success of the Czech centre-right since 1989. It will focus principally on the most successful party of the Czech right, the Civic Democratic Party (ODS) of former Czech Prime Minister (and current President) Václav Klaus. However, it will also discuss the fortunes of a number of smaller Christian Democratic, liberal and anti-communist groupings, insofar as they have, with varying degrees of success, sought to provide right-wing alternatives to Klaus's party. In comparative terms, the paper will suggest, the Czech centre-right represents an intermediate case. Although in Klaus's ODS, the Czech centre-right has been represented from an early stage by a large, stable and well institutionalised party, avoiding the fragmentation and instability of the Polish right, it has failed to achieve the degree of ideological and organisation concentration seen in Hungary. Indeed, since the mid-1990s, the Czech right has become increasingly divided and has in successive general elections since 1996 proved unable withstand the electoral challenge of the Czech Social Democrats (ČSSD).

After discussing the evolution and success of Czech centre-right parties between 1991 and 2002, the paper reviews a number of factors commonly used to explain party

\footnotetext{
* Dr Seán Hanley is Lecturer in East European Politics at the School of Slavonic and East European Studies, University College London. He has published a number of articles on party politics in the Czech Republic and is currently working on a book entitled The Rise and Fall of the New Czech Right.
} 
(system) formation in the region as they relate to the Czech centre-right. These include both structural-historical explanations and 'political' factors such as macroinstitutional design, strategies of party formation in the immediate post-transition period; patterns of party institutionalisation, charismatic leadership and ideological construction. It will argue that both the early success and subsequent decline of the Czech right are rooted in a single set of circumstances, which distinguish the Czech Republic from the other cases studied in this special issue. Key amongst these were the early institutionalisation of a dominant party of the mainstream right and the right's rapid and successful taking up of the mantel of technocratic, market-led modernisation.

\section{The Rise and Decline of the Czech Right}

\section{The Czech 'New Right'}

The first notable party of the right founded in post-communist Czechoslovakia was the Civic Democratic Alliance (ODA) created on 17 December 1989 by a group of neo-conservative dissidents and free market economists. However, the Alliance's lack of resources, theoretical preoccupations and immediate absorption into the broad Civic Forum movement, that oversaw Czechoslovakia's transition to democracy in 1989-90, limited its impact. However, through its foundation and subsequent sponsorship of the Interparliamentary Club of the Democratic Right (MKDP) within Civic Forum, it served to define the emergent Czech 'democratic right' in terms of Western-oriented, pro-market conservatism, whose primary goal was the dismantling communism and the enactment of social and economic transformation.

The principal and best known party of the centre-right in the Czech Republic is the Civic Democratic Party (ODS) formed in early 1991 on the basis of the free market, 
anti-communist right wing of a disintegrating Civic Forum. ODS is closely identified with its charismatic founder, the former Czechoslovak Finance Minister (1990-92) and former Czech Prime Minister (1992-7) Václav Klaus, who led the party from its foundation until December 2002, when he stood down to launch his successful bid the Czech Presidency. Like its smaller precusor, Klaus's party identifed itself as a Western style conservative party defined by issues of post-communist transformation.

Table 1: Election Results to Lower House of Czech Parliament 1992-2002

\begin{tabular}{|c|c|c|c|c|c|c|c|c|}
\hline Party & $\begin{array}{l}\% \\
\text { vote } \\
1992\end{array}$ & $\begin{array}{l}\text { Seats } \\
/ 200 \\
1992 \\
\end{array}$ & $\begin{array}{l}\% \text { vote } \\
1996\end{array}$ & $\begin{array}{l}\text { Seats } \\
/ 200 \\
1996 \\
\end{array}$ & $\begin{array}{l}\% \text { of } \\
\text { vote } \\
1998\end{array}$ & $\begin{array}{l}\text { Seats } \\
/ 200 \\
1998\end{array}$ & $\begin{array}{l}\% \text { of } \\
\text { vote } \\
2002 \\
\end{array}$ & $\begin{array}{l}\text { Seats } \\
1200 \\
2002 \\
\end{array}$ \\
\hline Civic Democratic Party (ODS)* & 29.73 & 76 & 29.62 & 68 & 27.74 & 63 & 24.47 & 58 \\
\hline 'Coalition’ & - & - & - & - & - & - & 14.27 & 31 \\
\hline Freedom Union (US) & - & - & - & - & 8.60 & 19 & - & (9) \\
\hline $\begin{array}{l}\text { Christian Democratic Union- } \\
\text { Czechoslovak People's Party (KDU- } \\
\text { ČSL) }\end{array}$ & 6.28 & 15 & 8.08 & 18 & 9.00 & 20 & - & $(22)$ \\
\hline Civic Democratic Alliance (ODA) & 5.93 & 14 & 6.36 & 13 & - & - & - & - \\
\hline Czech Social Democratic Party (ČSSD) & 6.54 & 16 & 26.44 & 61 & 32.32 & 74 & 30.20 & 70 \\
\hline $\begin{array}{l}\text { Communist Party of Bohemia and } \\
\text { Moravia (KSČM)** }\end{array}$ & 14.04 & 35 & 10.33 & 22 & 11.03 & 24 & 18.51 & 41 \\
\hline $\begin{array}{l}\text { Association for the Republic - } \\
\text { Republican Party of Czechoslovakia } \\
\text { (SPR- RSČ) }\end{array}$ & 5.98 & 14 & 8.01 & 18 & - & - & - & - \\
\hline $\begin{array}{l}\text { Society For Moravia and Silesia - } \\
\text { Movement For Self-Governing } \\
\text { Democracy (HSD-SMS) }\end{array}$ & 5.87 & 14 & - & - & - & - & - & - \\
\hline Liberal Social Union (LSU) & 6.52 & 16 & - & - & - & - & - & - \\
\hline
\end{tabular}

Results show parliamentary parties only. Centre-right parties italicised

*Joint list with Christian Democratic Party (KDS) in 1996

**Left Bloc coalition in 1992

Source: $w w w . v o l b y . c z$

In the early-mid 1990s the ODS was the dominant force in Czech politics and the lynchpin of the 1992-7 centre-right coalition governments, which negotiated the division of Czechoslovakia in late 1992, implemented many key policies of postcommunist transformation in the Czech Republic. Its smaller coalition partners were the Civic Democratic Alliance (ODA) and the Christian Democratic Union Czechoslovak People's Party (KDU-ČSL). The People's Party had existed as a 'satellite' party under communism, but its origins dated to the $19^{\text {th }}$ century. Drawing 
on historic bastions of support in rural Catholic regions of South Moravia and East Bohemia, KDU-ČSL was the only historic party other than the Communists to gain representation in Czech and Czechoslovak parliaments after 1989. However, its broader appeal was initially weakened by its confessional character and perceived collaboration with the old regime. ${ }^{2}$

\section{The Decline of the Czech Centre-Right}

By mid-1990s it had became evident that, rather than producing the post-communist economic miracle some had anticipated, the policies of the Klaus government had created an under-regulated, under-capitalised, inefficient private sector, dominated by politically connected, rent-seeking groups. The resultant economic malaise added to the momentum of the Czech Social Democratic Party (ČSSD), which emerged as the principal party of the Czech centre-left following the failure of the Czech successor party, the Communist Party of Bohemia and Moravia (KSČM), in 1993 to adopt a reformist course. The Czech Republic's economic problems also aggravated relations between Klaus's party and its coalition partners, both of which developed new programmatic positions critical of ODS. Whilst the Christian Democrats stressed their commitment to a 'social market', the Civic Democratic Alliance called for greater reliance on market forces to transcend the semi-private, semi-public 'bank socialism' of the Klaus era.

Such conflicts intensified when, against most expectations, the centre-right coalition narrowly failed to retain its parliamentary majority, continuing as a minority administration 'tolerated' by the opposition Social Democrats. In November 1997 the incipient crisis facing the Czech centre-right was brought to a head by a party financing scandal in ODS that led to the collapse of the Klaus government. Klaus's alleged complicity in the scandal prompted his coalition partners to withdraw from the 
government and caused a split in ODS itself, when senior figures in the party called his integrity and political judgement into question. Similar irregularities concerning anonymous donations were then uncovered in the smaller Civic Democratic Alliance, igniting tensions between neo-conservative former dissidents and liberal pragmatists in the Alliance, which saw it rapidly disintegrate as a political force. ${ }^{3}$ Factional conflict also broke out in Klaus's Civic Democratic Party (ODS), but proved less destructive. At a special party congress in Poděbrady in December 1997, the former Prime Minister - who claimed to have been unaware of the irregularities successfully mobilised grassroots support to resist pressure for his resignation by a decisive majority.

Klaus's defeated opponents, who included a significant section of ODS's parliamentary and party élite, left to found a new party, the Freedom Union (US) in February 1998. In early parliamentary elections in June 1998, despite recovering much apparently lost support, Klaus's ODS was out-polled by the Social Democrats, who became for the first time the largest Czech party. Although centre-right parties of the outgoing coalition regained a theoretical parliamentary majority, such were the tensions between ODS and its former allies, that Klaus unexpectedly opted to allow a minority Social Democratic government under Miloš Zeman to take office, on the basis of a written pact, the 'Opposition Agreement'. After losing office, Klaus's party attempted to realign itself by combining neo-liberal demands with conservative and nationalist themes, such as defending national interests against the EU, restricting immigration and resisting German demands to revise the legal status of the 'Beneš Decrees' expelling Czechoslovakia's ethnic German population in 1945-6. ${ }^{4}$ The Christian Democrats and Freedom Union responded to the new political situation by founding a new electoral alliance, the Quad-Coalition (4K), with the much diminished 
Civic Democratic Alliance and the small Democratic Union (DEU) party, which identified itself as pro-European and committed to completing unfinished reforms.

Despite growing public dissatisfaction with its cartel-like character, the 'Opposition Agreement' endured until scheduled parliamentary elections in June 2002. These were won by the Social Democrats under a new leader, Vladimir Špidla, the current Prime Minister. Špidla abandoned cooperation with ODS to work with the 'Coalition' grouping uniting the Freedom Union and the Christian Democrats, who became junior partners in a coalition government with a narrow parliamentary majority, on the basis of a opposition to shared ODS's euroscepticism.

The 2002 election results seemed to mark the failure of ODS's post-1997 realignment. Internal recriminations focused on Klaus, whom many powerful regional ODS organisations had come to consider an electoral liability, rather than an asset. In October 2002 Klaus announced that he would not stand for re-election as ODS chairman at the party's December 2002 congress, ostensibly to facilitate his campaign for the Czech presidency due to be vacated Václav Havel in February 2003. The election of Klaus as President by a joint session of the Czech Parliament in February 2003 with the support of Communist deputies, attracted by his resolute defence of the Beneš Decrees and promise to normalise relations with their party, provided a further political surprise. Some argued, however, that the presidential election result was more a personal triumph for Klaus and his informal team of advisers, than a victory for his party or the broader centre-right. ${ }^{5}$ Klaus's successor as ODS leader, Senator Miroslav Topolánek, a pragmatic politician with a regional power base in the industrial city of Ostrava, seemed to lack both personal authority or a clear political vision, leading to suggestions that Klaus's party might simply become a coalition of local politicians and business interests. ${ }^{6}$ As even sympathetic observers conceded, 
after the 2002 election, the Civic Democrats appeared ideologically and politically disunited and uncertain as to their future role in Czech politics. ${ }^{7}$ Despite being in government, the Christian Democrats and Freedom Union (US) also both experienced difficulties. As well as dissolving their electoral alliance, both parties suffered internal splits and changes of leadership related to their collaboration with the Social Democrats. ${ }^{8}$ Recent polling has consistently suggested that the Freedom Union's support had fallen below the level necessary to re-enter parliament. ${ }^{9}$

\section{Assessing the Success of the Czech Right}

Overall, the success of the Czech centre-right appears to represent an intermediate case between those of equivalent formations in neighbouring Poland and Hungary. Despite two electoral defeats and one major internal party crisis, the Civic Democratic Party (ODS) has avoided the organisational and electoral fragmentation and collapse of the centre-right in Poland. However, equally it has failed to gain the levels of support or concentration of the centre-right achieved by Hungary's FIDESZ through alliance building and the absorption of smaller organisations. Although in 1996 Klaus's party absorbed the tiny ex-dissident Christian Democratic Party (KDS) and elements of the influential anti-communist grouping, the Club of Committed Independents (KAN), ${ }^{10}$ it failed to take in more significant groupings, even those ideologically close to it such as the Civic Democratic Alliance (ODA).

As in Poland, an ideological and cultural division between neo-liberals and conservatives has represented a barrier to encompassing right-wing unity, although in the Czech case it is the neo-liberal right that is the dominant partner and the conservative Christian Democrats the more minor player. Perhaps more significantly, ODS also arguably failed to maintain the broad alliance between neo-liberals and anti- 
communists (discussed below) that underpinned it at its foundation. As early as 1994, radical anti-communists, previously been supportive of Klaus founded the Democratic Union (DEU), which polled three per cent in the 1996 elections, to campaign for a more 'moral' approach to transformation showing greater sensitivity to issues of historical justice. In the case of the Civic Democratic Alliance (ODA), despite merger discussions and informal understandings with Klaus's ODS in 1991 and 1992 - and, reportedly, a renewed offer to ODA élites in 1996 - policy disagreements, failure to agree merger terms and Klaus's dismissal of small, élite-based groupings as unimportant, obstructed alliance-building. ${ }^{11}$ Divisions among ODS élites in 1997-8 over the direction and management of the party led to a significant split and the foundation the Freedom Union(US), which rapidly took up the role played by the disintegrating Civic Democratic Alliance as spokesperson for a less statist brand of centre-right liberalism. As recently as 2002, the European Democrats (ED) a grouping founded by the former Civic Democrat Mayor of Prague, Jan Kasl, broke away from the party and successfully contested local elections. ${ }^{12}$ In purely political terms, despite the departure of Klaus and considerable leadership change within the Freedom Union, the participation of smaller centre-right parties in the current coalition government itself a legacy of the divisions generated by the break-up of the Klaus government further rules out initiatives at promoting centre-right co-operation.

Longer term electoral trends also appear unfavourable for the Czech centre-right. As table 2 indicates ODS's support has declined in every parliamentary elections to the lower house of the Czech parliament since 1992 from a peak of 29.62 per cent in 1992 to 24.57 percent in $2002 .{ }^{13}$ Moreover, calculation of the combined votes and seats won by liberal free market parties suggest that, until 1998, this bloc's support remained significant, but static at 35-36 per cent of the electorate. A similarly stable 
picture emerges for the broad Czech centre-right, including both liberal groupings and the Christian Democrats, which, with aggregate support of more than 40 per cent between 1992 - 1998, represented the minimum winning coalition capable of generating a parliamentary majority. However, leaving aside their well known problems of inter-party co-operation, the 2002 election saw a sharp decline in the combined vote of centre-right parties, that would have left them far short of a parliamentary majority. Given the absence of shared intellectual milieux and the pronounced economic populism of the Czech far right, in the Czech Republic it is perhaps not realistic to think in terms of a single bloc of 'right wing' parties extending from the fringe to the mainstream as in Hungary. ${ }^{14}$ Nevertheless, as table 2 indicates, the parallel decline of the Czech extreme right as an electoral force since 1998 would render even a hypothetical strategy of right-wing inclusion of the type pursued by FIDESZ irrelevant in a Czech contest.

\section{[TABLE 2 ABOUT HERE]}

However, despite the decline in its electoral fortunes and loss of national office, the key parties of the Czech centre-right remain stable and well established. The Civic Democrats are well represented in local and regional government and plays a key role in governing large municipalities, such as Prague and Brno, and regional authorities elected for the first time in 2000, where the ODS holds a majority of the governorships (hejtmanstvî). This reflects the party's success in building and maintaining a national organisational network with a presence in most major population centres and a stable national membership of approximately $20,000 .{ }^{15}$ The Christian Democrats too have a dense local organisational network and, particularly in 
regions of traditional support, are well established in communal and municipal politics. $^{16}$

\section{Explaining the Czech Right}

\section{The Historical Weakness of the Czech Right}

In many ways, the Czech lands were an unlikely setting for the emergence of a strong centre-right. In contrast to Hungary and Poland, where the post-1989 right was able to draw on powerful traditions of populism, conservative nationalism and political Catholicism dating back to the $19^{\text {th }}$ century, 'right-wing' forces in the Czech lands were historically weak and divided. Czech party development before 1938 broadly conformed to the pattern of cleavage-based party formation seen in Western Europe, albeit in a way strongly crosscut by the struggle for Czech national selfdetermination. ${ }^{17}$ However, the social forces that formed the bases of the traditional Right in many European countries, such as conservative aristocratic landowners or the Catholic Church, were politically weak or absent in the Czech case. ${ }^{18}$ Political forces that might have coalesced into a broad conservative or liberal Czech 'right-wing' were impeded from doing so both by the prominence of the 'National Question' in Czech politics and the framing of a 'progressive' Czech national identity by the dominant nationalist discourse. Before 1918 conservative land owning and liberal middle class élites therefore tended to found parties as 'national' formations, which by the late $19^{\text {th }}$ century were easily pushed aside by .the rise of mass confessional, class- and interest-based parties. ${ }^{19}$

The 'right wing' of the historic Czech party system inherited by Czechoslovakia in 1918 was both divided between an array of nationalist, Catholic and agrarian parties and disadvantaged by the progressive and left-liberal bias of Czechoslovakia's 
founding 'state idea'. To some extent, this pattern of party system development paralleled that in Scandinavia. ${ }^{20}$ However, given the presence within the new state of disaffected national minorities, governing coalitions in interwar Czechoslovakia, although shifting in ideological composition, tended to oppose 'state-forming', Czech-based parties to parties of the German and Slovak minorities, rather than blocs of left or right.

After the collapse of democratic interwar Czechoslovakia following the 1938 Munich Agreement, some figures from the interwar 'right' attempted to create an authoritarian pro-German Czech corporate state through the creation of a Party of National Unity $(\mathrm{SNJ}),{ }^{21}$ further weakening and discrediting the historic right. As elsewhere in Europe, the perceived collaboration of traditional right-wing parties in the 'Second Republic' (1938-9) and the Nazi-controlled Protectorate of Bohemia and Moravia (1939-45) prompted the Czech electorate to swing markedly to the Left after 1945. Moreover, even in the relatively democratic post-war conditions before the communist takeover in February 1948, two of the three historic 'right-wing' parties - National Democracy and the Agrarians - were banned for alleged collaboration. After 1948 official communist historiography assimilated the historic Czech 'right' to Fascism and reactionary foreign rule. After the collapse of the Prague Spring reform movement in 1968-9 official media extended the label 'right-wing' to proponents of radical reform and dissident critics of regime.

\section{Regime Legacies and Historical Pathways}

At the élite level Czech political debates are often dominated by crosscutting issues such as civil society, national identity and European integration. Nevertheless, at the party system level there is overwhelming evidence that left-right party competition in 
the Czech Republic has since its inception in the early 1990s been predominantly structured by divisions over the role of the state and the market. ${ }^{22}$ This has been underpinned by growing correlation between social class and party choice. Although parties on the Czech centre-right and centre-left draw support from a range of social groups, there has been a clear tendency for better educated, more urban and more prosperous groups of 'transition winners' to support the centre-right, and 'losers' the left and centre-left. ${ }^{23}$ Kitschelt and his collaborators see such patterns of left-right competition in the Czech Republic as conditioned by repressive, reform averse, nature of the 'bureaucratic-authoritarian' of communism in Czechoslovakia. This in turn is seen as a product of relatively high levels of pre-communist socio-economic modernity in the Czech lands, which, it is argued, furnished the communist regime with both an effective state apparatus and mass support from a sizeable and well organised working class. Left-right division after 1989, it is argued, thus centred on distributive issues, rather than moral or social issues, producing a free market, liberalconservative centre-right, rather than a national-populist bloc.

However, for all its strengths such broad structural-historical analysis does little to account for the strength of the Czech Right after 1989, the nature of its institutionalisation or changing patterns of inter-party competition and co-operation, which seem difficult to reduce to regime legacies. Moreover, even within an explanatory framework of regime legacies, as Fowler suggests elsewhere in this issue, is arguably necessary to note how such legacies, were transmitted through the structural location and intellectual discussions of counter-élites under late communism. Although conscious of the Czech lands' democratic heritage, the dissident movement that emerged in the 1970s developed an innovative, philosophically laden, discourse of human rights, 'civicness' and anti-politics 
sometimes overlapping with West European ideological models as points of reference, rather than seeking to build on pre-communist intellectual tradition. Indeed, it tended to be critical not only of communism - including the abortive reform era of the 'Prague Spring' - but also of historic Czech nationalism, which had, ultimately, been appropriated by the Left. Paradoxically, the 'transfer' of the Sudeten Germans in 1945-6, the subject of much samizdat criticism and reassessment, ${ }^{24}$ in removing the historic focus for right-wing Czech nationalism further undermined any prospect of its intellectual revival. Thus, despite isolated attempts by some dissident intellectuals to re-evaluate Austrophile Catholic conservatism and the National Democrat tradition of the $1920 \mathrm{~s},{ }^{25}$ emergent 'right-wing' counter-élites chose largely drew their inspiration from Anglo-American neo-liberalism and neo-conservatism. The informal dissident grouping around Pavel Bratinka and Daniel Kroupa, for example, established contacts with leading Western (neo-) conservative intellectuals in 1980s and subsequently crystallised into a right-wing 'civic current' within the Movement for Civil Liberties (HOS) formed in 1987 by leading figures within Charter $77 .^{26}$

An equally significant counter-élite can be found in the generation of younger neoliberal technocrats, who emerged on the margins of the 'Prague Spring'. ${ }^{27}$ Rather than being co-opted into the reformist wing of the regime or marginalised in opposition milieux strongly defined by the historical nationalism, as in Hungary and Poland, under Czechoslovakia's repressive post-1968 'normalisation', this group formed part of an outwardly uncommitted 'grey zone' between official power structures and independent political opposition. The presence of cohesive counter-élite groups as a product of the failure of the Prague Spring and the 'normalisation' regime, ${ }^{28}$ rather than the strength of opposition per se or longer term legacies of historical modernity, created the potential for (but did not guarantee) the emergence of a Czech New Right. 
This Right was to be 'new' both in the sense of importing Anglo-American New Right ideology and in seeking to make a conscious break with historical Czech political traditions, including those of the defunct historic Right.

\section{The Right as Vehicle for Technocratic Modernisation}

A further mediated 'legacy' specific to the Czech Republic was the centre-right's inclination and ability to project itself as an agent of political professionalism and technocratic modernisation. The literature on political parties in East Central Europe has often explained the renewed political appeal of reformed successor parties in states such as Hungary and Poland as result of their donning the mantle on professionalism and technocratic efficiency. ${ }^{29}$ As Fowler observes in this issue, in the post-communist context, such commitments amount in practice to the 'neoliberalisation' of these parties. However, there has been relatively little consideration of such factors in relation to the centre-right. ${ }^{30}$ In the Czech case the failure of the old regime to co-opt technocrats, who might furnish the basis of reformed, pro-market successor party and the absence of conservative-national right seeking to frame regime change as return to traditional moral and national values, it was the Right that first underwent 'neo-liberalisation', (re-)inventing itself as agent of socio-economic modernisation and transformation.

A pronounced clash between the political and organisational culture of neo-liberal technocrats and former dissidents had been evident from the earlier days of Civic Forum. ${ }^{31}$ A stress on political professionalism and business-like efficiency originated as a reaction against the ethos of non-bureaucratic, non-professional, informal civic participation prevalent in Civic Forum. Petr Havlík, the first Chief Secretary of the ODS's Head Office promised members that the party would 'remove all irrationalities 
and revolutionary habits and gradually establish a good system of a professional standard' describing ODS as 'an enterprise (podník) on a green-field site ... our shareholders are our members. ${ }^{32}$ This extended to a broader conception of the party as being primarily a efficient co-ordination device linking people - political élites and rank-and-file activists and voters - who shared common goals and interests. ${ }^{33}$ This end was the transformation of Czech society, which as the 1992 ODS programme noted was 'beyond individuals, .... it requires the institutionally based co-operation of people with common interests and a similar way of thinking' ${ }^{34}$

There is an extensive literature on economic and social transformation in the Czech Republic in 1990s. Much of it highlights the limitations, contradictions and unintended consequences of the coupon-based privatisation programme of the 1992-7 Klaus governments and, in particular, its failure to create effective ownership structures. Other writers have noted the Klaus administration's neglect of legal and regulatory frameworks and failure to reform public administration. Others have contrasted ODS's strident neo-liberal rhetoric with the reality of strong state influence in the economy, an extensive welfare state, and continued regulation of rents and utility prices. Diverse explanations for such uneven policy performance have been advanced. Some cite ideological belief in market forces, ${ }^{35}$ submerged nationalism, ${ }^{36}$ and calculations of electoral self-interest on the part of Klaus and his party. ${ }^{37}$ Other have highlighted the constraining legacies of a social liberal compromise forged by the 1990-2 Civic Forum-led government; the blocking of policy learning as a consequence of stable, majority government, ${ }^{38}$ or the need to utilise pre-existing managerial networks. ${ }^{39}$ Such debates are beyond the scope of this paper. Nevertheless, what does emerge clearly that is early dominance of Klaus's Civic Democrats was closely linked with their perceived ability to act as the only credible vehicle for 
successful post-communist transformation. The gradual accumulation of policy failures, the re-composition of the Czech centre-left and its formulation from the mid1990s of a credible transformation project of its own, sharing the same broad goals of modernisation and Europeanisation, undercut this dominance. ${ }^{40}$

\section{Macro-Institutional Factors}

Electoral Systems and Strategies for Party System Redesign

Although writers stressing regime legacies dispute its importance, ${ }^{41}$ institutional design - and, in particular, the choice of electoral system - is widely considered a crucial influence on the formation of parties and party systems in new democracies. Since the fall of communism, parliamentary elections to the lower house of the Czech parliament have used proportional representation based on closed party lists, large multi-member electoral districts and a five per cent threshold for representation. ${ }^{42}$ However, the electoral system, appears to have only a limited bearing in explaining the success of the Czech right. There is significant evidence suggesting that Czech electoral system may have blocked the consolidation and concentration of the centreright seen in Hungary, whose a mixed electoral system offers a very different set of incentives.

While erecting insuperable barriers to the electoral viability of some tiny ex-dissident groupings, the electoral system did permit the continued parliamentary existence small parties of the centre-right, such as the Christian Democrats, Civic Democratic Alliance (1992-98) and Freedom Union (1998-). It has also made launching (and voting for) small anti-communist formations appear a viable choice. The far-right Republicans (SPR-RSČ), for example, successfully broke into parliament in 1992 with slightly less than 6 per cent of the vote. The more, moderate Democratic Union, 
founded in 1994, failed to enter the Czech parliament in both 1996 and 1998, polling 2.80 and1.45 per cent respectively, arguably drawing votes from the centre-right.

Under Klaus, the Civic Democrats had a long-standing commitment to a bi-polar model of party competition of alternating blocs of left and right as a 'standard' and desirable form of politics. ${ }^{43}$ An important understanding of ODS and the Social Democrats in signing the 'Opposition Agreement' on 9 July 1998 - an understanding made explicit in its successor, the 'Patent of Toleration', signed on 14 January 2000 was that the two parties would engineer such an outcome through the introduction of a more majoritarian electoral system for elections to the lower house of parliament. ${ }^{44}$ Electoral reform was intended to 'reinforce the importance of the results of competition between political parties in accordance with the constitutional principles of the Czech Republic' by decreasing the representation (and hence the bargaining power) of smaller parties, in effect creating a two-party system. ${ }^{45}$ Counter-factual analysis of the impact the proposed amendments to the electoral law would have, which used votes cast in 1998, suggested that, even without any transfers of votes to larger parties, a two party system would effectively result. ${ }^{46}$ However, although an electoral reform bill agreed by Klaus's party and the Social Democrats was passed by the Czech parliament in 2000, the Constitutional Court ruled the law unconstitutional on 24 January $2001 .^{47}$

\section{Parliamentarianism and Successful Right-Wing Party Formation}

In a recent paired comparison of the Czech Republic and Poland, Saxonberg has argued that the relative success of the Czech centre right derives, in part, from the absence of incentives for charismatic leaders to pursue alternatives to party formation. By contrast, the relatively powerful, directly elected Presidency in Poland, he 
suggests, led a charismatic leader such Walesa to avoid founding or consistently supporting a party. ${ }^{48}$ Such institutional effects can be seen as particularly significant, given that, unlike communist successor parties, centre-right parties are typically 'new' formations, which will experience early problems of stabilisation and institutionalisation.

At an aggregate level, there is compelling evidence co-relating weak party structures in new democracies with moderate and strong presidentialism. ${ }^{49}$ Anecdotally, the fractiousness and weakness of pro-reform centre-right blocs in semi-presidential postcommunist states such as Romania and Russia confirm this association. However, detailed analysis of the Czech case suggests that, as in other cases discussed in this special issue, such institutional effects may be more apparent than real. Saxonberg is undoubtedly correct to argue that, in both Czechoslovakia and the Czech Republic, strong parliamentarianism and a weak Presidency elected by parliament made partybuilding the only realistic route to executive power for ambitious politicians. ${ }^{50}$ However, the implicit assumption that all charismatic leaders were ambitious politicians capable of 'rationally' reading and responding to institutional incentives is flawed. Despite the popularity of figures such as Klaus,Václav Havel was the dominant political personality in the Czech land, having acquired an almost mythic status as a symbol of regime change.

Upon becoming Presidental candidate in December 1989, Havel's distaste for formal political organisation and, in particular, party political organisation, led him to break all contact with the Civic Forum movement he had co-founded. Thereafter, he made no direct intervention in the movement's internal affairs until September 1990 and also declined to stand for the movement's Chairmanship - a post he himself had proposed - which he would arguably have won without difficulty. Havel's 'irrational' 
behaviour in refusing to seek power through involvement with a political party thus opened the way for the 'more rational' Klaus to win the post. This suggests that a more critical factor in explaining successful party formation are the cognitive frameworks through which new political élites approach post-transition politics.

\section{Micro-Institutional Factors}

The Break-Up of Civic Forum - Crafting Party Formation

As moderate centre-right parties in CEE are typically the 'successor parties' of opposition movements, the break-up of the broad civic movements formed in 1989-90 critical juncture in the formation (or non-formation) of centre-right parties. Much of the literature on civic movements in Eastern Europe attests to the difficulty of transforming broad, loose movement type organisations into lasting political structures. ${ }^{51}$ However, Klaus's Civic Democratic Party emerged in 1990-1 in precisely this way.

Civic Forum (OF) was formed in Prague on 19 November 1989 as an ad hoc committee-like grouping of counter-élites and opposition groups, bringing together Prague-based dissidents, striking actors and students, and social scientists and economists from the 'grey zone'. As mobilisation increased and the regime ceased to resist, local civic fora were created across the Czech Lands and by early 1990 the movement was a powerful, if loosely structured, national organisation heading a transitional government. In the succeeding months, the Forum formalised its organisational structures and identity, seeking to reconcile the horizontal, spontaneous, non-ideological movement structure developed during Velvet Revolution with the demands of office-holding and contesting parliamentary elections in June 1990. The movement's overwhelming victory in these elections and the 
expectations that the elected Czechoslovak and Czech government it headed would rapidly deliver coherent reform, exacerbated these contradictions and rapidly exposed internal divisions.

As Hadjiisky's research has impressively demonstrated, these divisions concerned not only ideological differences over the pace of market reform, decommunisation or the constitutional relationship of Czechs and Slovaks, but also conflicts between organisational interests within the Forum. ${ }^{52}$ Principal among these were (1) growing pressures from OF's full-time paid regional officials and elected representatives to recognise them as political professionals; and (2) discontent amongst grassroots activists that their views were (especially on decommunisation) were not represented by the movement's ex-dissident leaders. Such tensions were expressed from mid-1990 in the emergence of a 'right-wing' within the movement initially articulated by Bratinka and Kroupa's Civic Democratic Alliance (ODA), which defined the 'rightwing' position in terms of rapid economic reform, radical decommunisation and resistance to Slovak demands to greater autonomy for Czechoslovakia's two national republics. 53

However, leadership of the 'right' was rapidly taken over by Federal Finance Minister Václav Klaus. Klaus's unexpected election as Chairman of Civic Forum in October 1990, marked the rise of the Czech right as a majority coalition of dissatisfied, anticommunist grassroots activists, neo-liberal technocrats and right-wing dissident intellectuals not attracted by ex-dissident groupings such as ODA or the tiny Christian Democratic Party (KDS). Klaus's project to transform the Forum into an ideologically and organisationally well-defined party of the centre-right oriented towards electoral competition and the delivery of a programme social and economic transformation, rather than citizen participation, although not realised as envisaged, led to the 
movement's break up in February 1991 and the foundation of the Civic Democratic Party (ODS) two months later. ${ }^{54}$

The creation in ODS of such a broad and diverse coalition, albeit on smaller scale than that of OF itself, and its transformation into a durable political party represented a significant and unusually successful piece of political crafting. To some extent, this was conditioned by the repressive nature of Czechoslovakia's communist regime and by the mode of transition from communism. Given the suddenness of the 'Velvet Revolution' and numerical weakness of opposition groupings, allowed Civic Forum to emerge as unitary organisation, rather than a coalition of more developed opposition groups or the 'civil' wing of a trade union. The large number of grassroots Civic Forum participants with no ties to the pre-1989 opposition and in search of political identity also favoured transformation. Czechoslovakia's relatively late transition process also enabled Klaus and others to learn from the break-up of Solidarity in Poland in mid-1990. However, to a considerable, the successful formation of ODS must be regarded as the result a contingent choices rather than outcome pre-determined outcome. As Klaus's chief aide recalls, in October 1990 hours before the election for the Chairmanship of Civic Forum, which was to launch his career as a party leader, a reluctant Klaus had to be persuaded to stand. ${ }^{55}$

\section{The Decline of the Czech Centre-Right as Problem of Institutionalisation}

A newly founded political party can be regarded as an organisational solution to a collective action problem, in which participants (members, voters) exchange resources (financial, material, technical, time) to generate political outcomes which would not be achievable individually. A party becomes organisationally stabilised relatively quickly when such resource flows and exchanges are regularised and settle 
into some kind of equilibrium. In the longer term, however, members and voters may begin to identify with the party to such an extent that the party is seen as an end in itself, leaving behind the instrumental goals of its founders and initial supporters. Such a process - and the air of permanence and durability it produces - is widely termed institutionalisation. ${ }^{56}$

ODS's formation (and its own view of its formation) was as a rational response to the problem of co-ordinating and mobilizing political support for market reform and other policies. By the mid-1990s ODS had (seemingly) delivered these public goods and had at the same time stabilised itself organisationally, acquiring enough votes and resources to sustain itself and maintaining a rough balance between internal interests, competing élites and élite and and grassroots actors. However, despite generating electoral support and a degree of voter identification unusual for a 'new' party in East and Central Europe, the party could not be regarded as institutionalized in the sense described above. ODS's internal party crisis of the mid-1990s, which culminated in the split of 1997-98 represented a breakdown in the institutionalisation process. Paradoxically, this breakdown was caused by the same factors that had initially allowed ODS to form and stabilise so quickly and so successfully: charismatic leadership, internally democratic organisation and ideological militancy. In choosing to support Klaus almost regardless of the circumstances of the funding scandal or the party's record in office, the majority of ODS members in effect chose to make the party a formation based increasingly on a bond of trust with its charismatic founder and leader. Rather than outgrowing its charismatic founder, the crisis saw the reassertion of Václav Klaus's personal authority and prominence allowing him to develop his personal policy agendas (on, for example, Europe) without being checked by the rival élites. ODS was both too stable to expand the centre-right through party 
breakdown - the model described by Fowler in the case of the MDF and FIDESZ and too weakly institutionalised to expand through a more normal process of replacing its leadership, renewing its ideology and identity and embracing new alliance-building tactics.

\section{Critical Elections as Critical Junctures}

1992 and 1998: From Breaking the Left to Braking the Left

Klaus's Civic Democratic Party took over not only the bulk of the Civic Forum's local and regional assets and organisation, but, in the 1992 Czechoslovak and Czech elections also attracted some 55 per cent of its voters. ${ }^{57}$ In successfully taking over both the resources, electorate and pro-reform mission of Civic Forum, Klaus's ODS thus established itself as the dominant force the right. In doing so, it blocked off the growth potential not only of small ex-dissident parties such as ODA and KDS, but also those of rivals threatening to create establish an alternative Right. Principal amongst these were the Christian Democrats and a newly emergent militant and populist anti-communist right, which was in 1991-2 able to attract growing levels of publicity, popular interest and electoral support. In the event, the electoral breakthrough achieved in June 1992 by Miroslav Sládek's far right Republican Party (SPR-RSČ) was limited. Moreover, in rapidly agreeing the dissolution of the Czechoslovak federation after the election with Vladmír Mečiar's Movement for a Democratic Slovakia (HZDS), now the dominant force in Slovak politics, Klaus's Civic Democrats closed off a further possibility. With the passing of federal, CzechoSlovak party system, the fragmented Czech left was cut off from more economically populist Slovak parties with which it might have made common cause. ${ }^{58}$ 
Six years on, the 1998 election marked a further critical juncture for the Czech centreright. In its 1998 election campaign ODS had called for a mobilisation of its supporters against a centre-left, which it once again depicted as a danger to reform and democratic development. However, when the election results failed to produce a viable majority government - principally, because of the Freedom Union's unwillingness to enter a coalition with either ODS or the Social Democrats - Václav Klaus. The Agreement and its successor, the Patent of Toleration, were formal pacts, which committed ODS to support the continuation in office (but not all the legislation of) a minority Social Democratic government. The agreements also guaranteed ODS key posts in parliament and (informally) in the management structures of public bodies. As noted above, the two signatories also agreed to enact a number of mutually beneficial constitutional and legislative changes, principally electoral reform. ${ }^{59}$

ODS justified the Opposition Agreement as a pragmatic and realistic arrangement, which would maintain political stability and exercise a 'braking' effect on the Social Democrats. In this view, the Agreement did not mark the suspension of left-right competition, but merely transferred it to a new setting. ${ }^{60}$ Critics saw it as a cynical exercise in clientelistic power politics, which made a nonsense of pretended ideological divisions. ${ }^{61}$ Such discussions are, however, beyond the scope of this paper. What does seem clear, in hindsight, nevertheless is that Klaus's strategic initiative in July 1998, even if originally intended as a pragmatic response to temporary political deadlock, has weakened the possibility of a resumption of bi-polar left-right competition.

Firstly, the Opposition Agreement provided a focal point for ideological rethinking within the Civic Democratic Party, which led it to stress differences with smaller 
centre-right parties, rather than the left. The most important such difference was the party's new stress on 'national interests', a stress whose traditionally nationalist framing of Czech interests in juxtaposition to those of Germany was widely shared in the Czech left. As the Czech presidential election of 2003 graphically illustrated, in the Czech context, in marked contrast to the Polish and Hungarian cases, the revival of traditional nationalism can tends to blunt left-right, ideological divisions even where, as in relations with the Communists, they are rooted in the regime-opposition divide. Secondly and paradoxically, the Opposition Agreement has legitimised leftright co-operation even for those centre-right groupings opposed to it. In entering into coalition with the Social Democrats in 2002, Freedom Union politicians deployed essentially the same arguments, that the coalition would promote Czech EU accession and avoid making the centre-left dependent on the Communists.

\section{The 2002 Election as Critical Juncture: the Failure of the Quad-Coalition}

From the mid-1990s, under the chairmanship of Josef Lux, the Christian Democrats sought to reposition themselves as a third force in Czech politics offering a form of moderate conservatism, which would appeal to voters beyond the party's traditional rural Catholic and regional constituency. Although partially successful in diversifying the party's electorate, this strategy failed significantly to increase the Christian Democratic voter, leaving the dream of building a 'Czech CDU' unrealised. ${ }^{62}$ However, the breakaway of the Freedom Union as a liberal anti-Klaus formation and the signing of the Opposition Agreement, which sought to exclude small parties from the party system through electoral reform, created the basis of a new alliance. After initial pragmatic co-operation in the November 1998 local and senatorial elections, in mid-1999 four smaller centre-right parties, the Freedom Union, Christian Democrats, 
Civic Democratic Alliance and Democratic Union (now shorn of much its earlier radical anti-communism) agreed to form an integrated electoral bloc, the QuadCoalition (Čytrkoalice). ${ }^{63}$

Although deeply critical of Klaus's ODS, the Quad-Coalition (4K), nevertheless, framed itself within the liberal, anti-communist discourse of reform, modernisation and Europeanisation, characteristic of the Czech centre-right. Its founding 'St. Wenceslas Day Agreement' of 28 September 1999 thus pledged it to 'tackling political drift (marasmus), effectively countering growing communist influence, solving our country's current problems and leading it to the European Union'. ${ }^{64}$ As Lux had anticipated in 1998 before leaving politics through illness, the grouping also seemed to have the potential to create an influential fusing liberalism and moderate conservatism through its commitment to civil society, decentralisation and European integration. ${ }^{65}$ In 2000, 4K enjoyed further electoral success, making sufficient gains in the Senate, to block constitutional change and delay ordinary legislation. ${ }^{66}$ In November 1999 mass demonstrations against the perceived political stagnation brought about by the Opposition Agreement took place on the streets of Prague and other cities. In December 2001 similar mass protests and strikes by journalists took place against perceived political interference in the management of Czech Television by the two Opposition Agreement parties. ${ }^{67}$ This suggested that the Quad-Coalition, whose leaders supported both protests and sought to collaborate with the civic initiatives that had organised them, might be able to form a wider societal coalition to articulate a powerful public mood for change.

However, almost from its inception, $4 \mathrm{~K}$ was undermined by divisions of the type that that had plagued similar centre-right coalition groupings in Poland and Slovakia. These centred on rivalries between member parties, aggravated by their 
disproportionate size, and the weakness of coalition leadership structures to enforce decisions. Politicians in the four member parties were inconsistent and divided as over the extent to which $4 \mathrm{k}$ should be integrated into a single party or bloc. In the case of 4k, it was the strongest coalition partner, the Christian Democrats (KDU-ČSL), whose mass membership, long party tradition and distinct electorate, marked it out from other smaller, liberal and anti-communist coalition members, that became a source of instability. Rival factions within KDU-ČSL tended to use the coalition framework as an additional means of pursuing their own intra-party conflict. ${ }^{68}$ More significantly, however, the Christian Democrats became increasingly unwilling and unable to meet the programmatic and political demands of 4K's smaller parties. Following the absoption of the Democratic Union (DEU) by the Freedom Union (US) in October 2001 (creating US-DEU), in January 2002 Christian Democratic intensified pressure on the smallest $4 \mathrm{~K}$ member, the Civic Democratic Alliance, to resolve its longrunning problems or merge with US-DEU. When ODA refused this perceived ultimatum and withdrew from $4 \mathrm{~K}$, the Quad-Coalition framework collapsed. Although replaced by a looser alliance between the Christian Democrats and the Freedom Union-Democratic Union ('Coalition'), the potential for broad liberalconservative bloc to rival ODS had dissipated. The June 2002 election results duly confirmed the position of the two 'Coalition' members as minor parties. ${ }^{69}$

\section{Political Agents and Political Agency}

\section{The 'Klaus Phenomenon'}

Many discussions of the Czech right and Czech politics generally tend to focus on Václav Klaus, often in juxtaposition to Václav Havel. ${ }^{70}$ However, as Haughton suggests in previously published work, while overstressed empirically, the role of 
charismatic individuals in post-communist politics is worryingly under-theorised. ${ }^{71}$ Despite its democratic and representative mechanisms, which sometimes checked Klaus on internal matters, the Civic Democratic Party was from the outset dominated by the charismatic and forceful leadership of its founder. In April 1991, Miroslav Macek, an ODS Deputy Chairman commented that '...it is a peculiarity of the party [ODS] that today it stands and falls with the personality of Václav Klaus, ${ }^{72}$ 'the party Chairman is not selected. He simply exists. (....) He is simply there and we all know it' ${ }^{73}$ Eleven years latter, on the eve of Klaus's departure as leader one of his colleagues conceded that Klaus's moustache and glasses were as much, if not more recognisable, as a symbol of ODS, than its official logo. ${ }^{74}$ It has been widely observed that the self-confident, formal, well-dressed, tennis playing Klaus personified (and was projected as personifying) the political optimism and impatience of the Czech centre-right of the early 1990s, as well as its belief in professionally administered market-led solutions. As optimism concerning transformation waned, such qualities were increasingly negatively perceived as the 'arrogance of power' ${ }^{75}$ Like Viktor Orbán, Klaus was also able to portray himself as an outsider challenging metropolitan intellectual élites disconnected from the concerns of ordinary people living in small town and provincial settings. ${ }^{76}$

However, perhaps the best clue to understanding the role of charisma in relation to centre-right party formation are Klaus's own comments after being elected OF Chairman in October 1990, that he wished to be 'the symbol of a programme not yet written' ${ }^{77}$ Charismatic leaderships provide a personal and immediate focus for identification by members and voters at a time when political programmes are likely underdeveloped, voters may still face cognitive difficulties choosing between parties and programmes and loyalty to newly formed organisations is inevitably weak. It 
seems necessary, however, that charismatic leaders should be committed to developing party organisation.

\section{Ideological (Re)construction: From Neo-Liberalism to National Interests}

Communist regimes suppressed the public sphere and monopolised political discourse. In post-communist democracies the re-establishment of ideological discourses of left and right is an important means of creating the new political identities necessary to provide a meaningful framework for political action. The weaknesses of civil society and well understood social interests also gives ideological construction a particularly important role in orienting action in the early posttransition period. Politicians in early post-communist politics can therefore be seen not only as political entrepreneurs, but also as ideological entrepreneurs. In the Czech context, right-wing political entrepreneurs such as Klaus succeeded in framing both a new discourse of political organisation and of post-communist transformation, which grounded imported New Anglo-American Right ideas in a Czech post-communist context. Both served to reinforce the support, cohesion and power of ODS and the centre-right de-legitimise opponents on the centre-left. ${ }^{78}$

The ideological discourse initially developed by ODS was an innovative synthesis of Hayekian neo-liberalism and aspects of Czech nationalism. It argued that the free market, political parties, ideologies of left and right and Western international institutions were 'tried and tested' and 'standard' forms of organisation, which could and should be quickly re-established in the Czech lands. Opponents on the centre-left, who wanted a greater role for social movements and civil society in the political process or for a greater role for the state in economic reform were, it was argued, consciously or unconsciously, seeking 'Third Ways' between Soviet-style 
communism and the West European mainstream. Such thinking, it was argued, echoed the failed reform communism of the 1960s. While arguing that it was ideologically conservative, the new Czech right-wing discourse, was self-consciously radical, even 'revolutionary', in both its desire to break with the (communist) past and in its disdain for most pre-communist Czech thinkers and parties, viewed as too provincial or too collectivist. ${ }^{79}$ Such neo-liberal conservatism stressed its links with the past, by suggesting in a non-specific way that affinity with the free market was rooted in the Czech national character and tradition. ${ }^{80}$

However, after losing office in 1997, Klaus's party underwent a significant degree of ideological reconstruction and realignment, which saw it rediscover previously submerged traditional Czech nationalist paradigm. To a considerable extent, ODS's identity as an 'Anglo-Saxon' neo-liberal conservative party, rather than a Christian Democratic party on the German or Austrian model, was a conscious assertion of Czech national identity and independence against the dominance of Austro-German influences in Central Europe. ${ }^{81}$ Veiled anti-German undercurrent can also be detected in many ODS statements on European integration during the early-mid 1990s. However, after 1997 ODS's ideological discourse shifted away from Western neoliberalism as a point of reference, instead stressing the notion of defending Czech 'national interests' within an enlarging EU. In doing so started to draw on traditional Czech nationalist paradigms. ${ }^{82}$ Its April 2001 Manifesto of Czech Eurorealism, for example, attempted to align ODS's preferred neo-liberal model of European integration with the Czech national tradition, claiming that liberal-nationalist thinkers of the $19^{\text {th }}$ century such as Havlíček, Palacký and Masaryk were 'strikingly close to Anglo-Saxon liberal-conservative thought' ${ }^{83}$ 
As was the case with Hungary's FIDESZ, a key element in ODS's political success appears to lie with its leaders' ability to frame a new ideological discourse of 'rightness' relating substantially to post-communist transformation. However, in challenging the consensual, anti-political 'ideology' of Civic Forum, ODS's ideology re-defined the means, but not the ends of Czech post-communist transformation, rather than reacting against a transformation process seen as having fundamentally 'gone awry' as was the case with Hungary's FIDESZ. There are, however, parallels between FIDESZ's turn from the liberal camp to 'national revival' and ODS's post1997 turn from neo-liberalism to 'national interests'. Both arguably reflected the limitation of liberalism as a durable ideology for a broad centre-right in East Central Europe. However, in the Czech case it was waning of the big issues of postcommunist transformation - and ODS's loss of credibility as vehicle for that transformation - that prompted ideological realignment, rather than competitive pressures on the liberal 'centre' as was the case in Hungary.

\section{Conclusions}

The Civic Democratic Party (ODS) is the most significant centre-right formation in modern Czech political history. The party's origins can be traced to the reactions of Czech counter-élites to the collapse of the reform communism in 1968 and the 196989 'normalisation' period and subsequently - in combination with other groups- to the challenges of post-communist transformation. Late communism in Czechoslovakia - and the Czechoslovak mode of exit from communism that flowed from it- created a favourable opportunity structure for the early and successful formation of ODS as neo-liberal party championing socio-economic transformation. Key elements in this opportunity structure were the location of technocratic counter- 
élites, the ideological complexion of opposition groupings and the nature of Civic Forum as a transitional civic movement. Despite this, political strategy and contingent choices in the period 1990-2 can also be seen to have played an important role in translating opportunities a into strong, organisationally stable centre-right.

However, the circumstances that led to ODS's rapid formation and early dominance subsequently limited the concentration and consolidation of the centre-right in the Czech Republic. As well as being divided by ideological and cleavage differences from the small Christian Democratic right and populist far right, the tightly organised, charismatically-led Civic Democrats consistently failed to incorporate smaller centreright liberal groups. To some extent, this failure of concentration was abetted by the incentives offered by a Czech electoral system. From the mid-1990s, an accumulation of policy failures enabled the rise of a strong centre-left opposition, which shared the same broad transformation goals of modernisation and Europeanisation, and the gradual displacement the centre-right from power.

The subsequent realignment of the Czech centre-right resulting from the Opposition Agreement of 1998, although allowing both Klaus and his opponents to share power in the short-term, has further divided the Czech centre-right as a bloc. However, although the result of contingent choices in 1998, in many ways the pattern of leftright co-operation established in the Czech Republic - which appears exceptional in the region - should not surprise us. Despite its rhetoric of 'Third Ways', in the Czech context the regime-opposition divide ran not between centre-left and centre-right, as in Hungary and Poland, but within the left (dividing the Social Democrats from the Communists). Nevertheless, it remains to be seen whether the Czech centre-right will re-unite and re-assert itself, or whether it will remain within the confines of the pattern of limited success analysed in this article. 
${ }^{1}$ An earlier version of this article was presented at the European Consortium for Political Research General Conference, Marburg, Germany,18-21 September 2003. I would like to thank participants for their comments and to acknowledge the support of the British Academy in providing a travel grant enabling me to attend the conference.

${ }^{2}$ In the 1990 election campaign the perception of collaboration was reinforced by the revelation that its then leader, Josef Bartončík was listed in the records of the former communist secret police as an informer.

${ }^{3}$ The Alliance thus failed to contest the 1998 parliamentary elections. In the June 2002 elections after leaving the Quad-Coalition, it run an independent list, which received 0.50 per cent.

${ }^{4}$ See S. Hanley, 'Europe and the Czech Parliamentary Elections of June 2002', Royal Institute of International Affairs/ Opposing Europe Research Network Election Briefing No. 5, July 2002 http://www.riia.org (accessed 7 March 2004).

${ }^{5}$ See J. Urban, 'The Making of a Czech President', East European Perspectives, Vol. 5, No. 8, 16 April 2003, http://www.rferl.org/eepreport/2003/04/8-160403.html (accessed 1 June 2003).

${ }^{6}$ Reports suggested that Miroslav Topolánek was essentially seeking to balance out all major organisational and regional interests in ODS, rather than undertaking major new ideological initiatives. New ODS policy was said to be driven by individual ODS Shadow Ministers. See L. Bek, 'Topolánek nezvládl sjednotit ODS', Právo, 5 September 2003, p. 1. 
7 See B. Pečinka, 'Komentář: ODS mezi stagnací a růstem', Proglas, No. 2001/4 (2001) online edition and 'Budoucnost české pravice', Proglas, No. 8/2002 (2002), pp. 11-13.

${ }^{8}$ After the departure of Josef Lux in 1998, the Christian Democrats were led by Jan Kasal (1998-2001), Cyril Svoboda (2001-3) and Miroslav Kalousek (2003 -date). Since it foundation in 1998, the Freedom Union has been led by Jan Ruml (19982000), Karel Kühnl (2000-1), Hana Marvanová (2001-2002), Ivan Pilip (acting leader 2002-3) and Petr Mareš (2003-date)

${ }^{9}$ The most recent CVVM poll at the time of writing recorded the Freedom Union's electoral support at 2.5 per cent. 'CVVM: soc. dem spadl na 14 procent', Právo, 26 February 2004, p. 3.

${ }^{10}$ The majority of KAN delegates rejected the merger agreement at a special conference leading to a split in the organisation.

11 Daniel Kroupa and Pavel Bratinka cite ideological differences and Klaus's indifference as the reason for the failure to merge. D. Kroupa, Svoboda a rád (sváteční rozhovory) (Prague: Éós, 1996), p. 15-20 and M. Hamerský and P. Dumin (eds), 10 let na straně svobody (kronika ODA z let 1989 - 1999), (Brno: Bachant, 1999), pp. 24-5, 28. However, there is evidence that the Alliance's wish to enter Klaus's new party as a collective member was the real stumbling block. See comments by ODA representative Žegklitz at the Civic Forum Political Club, as reported in Infórum, No. 54/91, 4 January 1991. Klaus also cites his refusal to compromise on the principle of individual membership as the obstacle. V. Klaus, První zpráva (Prague: Cartoonia, 1993), p. 65.

12 The European Democrats won 18.3 per cent of the vote in Prague in the November 2002 local elections. 
${ }^{13}$ ODS's highest national vote was $33.9 \%$ in the ballot to the lower house of the Czechoslovak Federal Assembly in 1992.

${ }^{14}$ See M. Mareš, Pravicový extremismus a radikalismus $v$ České republice (Brno : Barrister \& Principal, 2003).

15 ODS's own figures suggest membership peaked at 23,269 in 1992, declining sharply to 16,289 after the party lost office in 1997 , before recovering to 18,908 at the end of 2000. See L. Benešová, Kronika ODS: 10 let historie, (Prague: ODS, 2001), published in electronic form at www.ods.cz (accessed 1 February 2004).

${ }^{16}$ The Christian Democrats currently have 9.58 per cent of elected communal and municipal councillors, marginally more than the Civic Democratic Party, although represent smaller communes. The Freedom Union -Democratic Union, by comparison, has only 0.72 per cent of local councillors. See www.volby.cz (accessed 5 March 2004).

${ }^{17}$ See, for example, L. Kopeček, ‘Aplikace Rokkanovské theorie cleavages na české politické strany na počatku éry masové politiky“, Středoevropské politické studie, Vol. 4, No. 2-3 (2002), published electronically at www.iips.cz (accessed 15 September 2003). One peculiarity of the pre- 1938 Czech party system was the presence of both a Catholic and an agrarian party.

${ }^{18}$ The (re)emergence of the Czechs as a political nation from early $19^{\text {th }}$ century largely excluded the aristocracy as a pro-Habsburg interest. Similarly, the Catholic Church, although institutionally and numerically dominant in the Czech lands, was seen as ambivalent towards aspirations for national self-determination.

${ }^{19}$ B. Garver, The Young Czech Party 1874-1901 and the Emergence of a Multiparty System, (New Haven and London: Yale University Press, 1978). 
${ }^{20}$ See G. M. Luebbert, Liberalism, Fascism, or Social Democracy : Social Classes and the Political Origins of Regimes in Interwar Europe (Cambridge: Cambridge University Press, 1991). A key difference with the Scandinavian context was the fragmentation of the Czech Left, which reflected the divisive effect of the National Question and the strength of the Communist Party of Czechoslovakia.

${ }^{21}$ See J. Rataj, O autoritativní národní stát: ideologické proměny české politiky $v$ Druhé republice 1938-1939. (Prague: Karolinium, 1997).

${ }^{22}$ See G. Evans and S. Whitefield, 'The Structuring of Political Cleavages in PostCommunist Societies: the Case of the Czech Republic and Slovakia', Political Studies, Vol. 46, No. 1 (1998), pp. 115-39; H. Kitschelt, Z. Manfeldová, R. Markowski and G .Toka, Post-Communist Party Systems: Competition, Representation and Inter-party Collaboration (Cambridge: Cambridge University Press, 1999); K. Vlachová, 'Levice a pravice v České republiky v letech 1996-2000’ in Z. Manfeldová and M. Tuček, Současná česká společnost (Prague: Sociologický ústav, 2002) pp. 254-70; K. Krause, 'Once More unto the Breach: The Politics of Cleavage in Slovakia and the Czech Republic', paper presented at the Annual Meeting of the APSA, Boston, 29 August - 1 September 2002.

${ }^{23}$ See, for example, P. Matějů and B. Reháková, 'Turning left or class realignment? Analysis of the Changing Relationship between Class and Party in the Czech Republic 1992-1996', East European Politics and Societies, Vol.11, No.3 (1997), pp. 501-42 and B. Reháková, 'Social Stratification and Voting Behaviour' inVečerník and Matějů (eds), Ten Years of Rebuilding Capitalism: the Czech Republic after 1989, pp. 228-250 and Krause, 'Once More unto the Breach'. 
${ }^{24}$ See B. Abrams, 'Morality, Wisdom and Revision: the Czech Opposition of the 1970s and the Expulsion of the Sudeten Germans', East European Politics and Societies, Vol. 9, No. 2 (1995), pp. 234-55.

${ }^{25}$ Principally the writings of Petr Pithart and the Střední Evropa group. See P.

Pithart, Dějiny a politika (Prague: Prostor, 1990) and M. Laruelle, “Střední Evropa': Une autre ecriture de la nation? (Prague: CEFRES Documents de travail No. 4, 1996).

${ }^{26}$ See P. Oslzlý (ed.), Podzemná univerzita (Brno: Centrum pro studium demokracie a kultury,19930 and B. Day, The Velvet Philosophers 9Oxford: Claridge Press, 2001).

${ }^{27}$ See S. Hanley 'The New Right in the New Europe? Unravelling The Ideology of “'Czech Thatcherism', , Journal of Political Ideologies, Vol. 4, No. 2 (1999), pp. 163-89 and G. Eyal, The Origins of Postcommunist Elites: from Prague Spring to Breakup of Czechoslovakia (Ann Arbor: University of Minnesota Press, 2003), pp. 135-93.

${ }^{28}$ Structural-legacy arguments have difficulty explaining the failure of the 'Prague Spring', which appears to be a critical juncture when more than one path of political development was open, whose outcome was dependent on the contingent choices of political actors (including external actors in the USSR). In structural-historical terms, arguably the same forces, which generated 'bureaucratic authoritarian' opposition to reform also generated the powerful reform communist movement itself.

${ }^{29}$ For example, A. Bozóki, 'The Ideology of Modernization and the Policy of Materialism: The Day After the Socialists', Journal of Communist Studies and Transition Politics, Vol. 13, No.3 (1998), pp. 56-102. 
${ }^{30}$ Much of the British politics literature of the 1980s on 'Thatcherism' does, however, suggests that, despite a conservative social policy agenda, the Conservative Party of Margaret Thatcher should, should be regarded primarily as an agent of market-led modernisation. In this sense, the Czech New Right can be seen as paralleling its Western ideological models. See S. Hall and M. Jacques (eds), The Politics of Thatcherism, (London: Lawrence \& Wishart, 1983) and S.Hall, The Hard Road to Renewal: Thatcherism and the Crisis of the Left (London: Verso, 1988).

${ }^{31}$ As one Charter 77 signatory wryly observed '[a]ll the other people in Civic Forum wear sweaters and call each other ty, but these gentlemen wear ties and say vy'. P. Uhl, 'The Fight For Socialist Democracy in Czechoslovakia', New Left Review, No. 179 (1990), pp. 11-19. Citation p.15.

32 'Vážení práátele', Bulletin ODS, No. 11, 15 May 1991.

${ }^{33}$ See article 2 of the first ODS Statutes on the function and role of the party. Stanovy ODS ( Prague: ODS, 1991).

${ }^{34}$ Svoboda a prosperita, (Prague: ODS, 1992), p.2.

${ }^{35}$ H. Appel, 'The Ideological Determinants of Liberal Economic Reform: the case of Privatization', World Politics, Vol.52, No.4 (2000), pp.520-54.

${ }^{36}$ P. Rutland, 'Thatcherism, Czech-style: Transition to Capitalism in the Czech Republic' Telos, No. 94 (1992-93), pp. 104-129 and S. Holmes, 'The Politics of Economics in the Czech Republic', East European Constitutional Review 4 (1995), pp. 52-5.

${ }^{37}$ M. Dangerfield, 'Ideology and Czech Transformation: Neoliberal Rhetoric or Neoliberal Reality', East European Politics and Societies, Vol. 11, No. 3 (1997), pp. 436-67. 
${ }^{38}$ M. Orenstein, Out of the Red: Building Capitalism and Democracy in Postcommunist Europe (Ann Arbor, MI: Michigan University Press, 2001), ${ }^{39}$ D. Stark and L. Bruszt, Postsocialist Pathways: Transforming Politics and Property in East Central Europe, Cambridge University Press, 1998.

${ }^{40}$ On social democratic strategies for transformation, see P. Machonin P. Št'astnová, A Kroupa and A Glasová, Strategie sociální transformace české společnosti (Brno: Doplněk, 1996).

${ }^{41}$ Kitschelt et al, Post-Communist Party Systems, pp. 35-6, 157-96, 218-9.

${ }^{42}$ Voters are able to cast a limited number of 'preference votes' for individual candidates on a list, which can have the effect of moving them to the top of the list. ${ }^{43}$ For example, addressing his party’s conference in December 1996 Klaus expressed satisfaction that the elections had 'made Czech politics more transparent ...marginal and poorly defined parties have disappeared. (...) there are two basic paths, two basic visions (....) represented, on one hand by ODS and, on the other by the Social Democrats'. V. Klaus, Obhajoba zapomenutých myšlenek (Prague: Academia, 1997), pp. 110-20. Citation p. 116.

44 ‘Smlouva ODS a ČSSD o výtvoření stabilního politického prostředí v zemi’, Lidové noviny, 10 July 1998, p.2, Article VII and 'Tolerační patent', agreement no. 2 http://www.ods.cz (accessed 6 March 2004).

45 'Zeman je skutečný politik, kterého odmítám podceňovat', Lidové noviny, 10 July 1998, pp. 1 and 5. Citation, p.5. ODS initially preferred a simple pluarlity system on British lines. However, under pressure from the Social Democrats and - after the November 2000 Senate elections - unable to command the necessary constitutional majority - the two parties agreed on a less proportional form of PR. 
${ }^{46}$ See T. Kostelecký, 'Navrhované zmeny volebního zákona vzeslé z dodatku “opozicní smlouvy” v roce 2000 a jejich mozné dusledky’, Sociologický casopis, Vol.36, No.3 (2000), pp.299-306.

${ }^{47}$ The 1992 Czech constitution specifies that proportional representation must be used for elections to the lower house of parliament. M. Klíma, Kvalita demokracie v Ceské republice a volební inženýrství (Prague: Radix/Marshall, 2001), pp. 108-122. A second electoral law reducing the proportionality of the previous system by increasing the number of electoral districts from six to fourteen was passed in January 2002 and used for the June 2002 elections.

${ }^{48}$ S. Saxonberg, 'The Influence of Presidential Systems', Problems of Postcommunism, Vol. 50, No.5 (2003), pp. 22-36.

${ }^{49}$ See M. Shugart, 'The Inverse Relationship between Party Strength and Executive Strength: A theory of Constitutional Choices', British Journal of Political Science, Vol. 28, No. 1 (1998), pp. 1-29.

${ }^{50}$ Moreover, the Constitution of the Czech Republic, whose Presidency is weaker than that of post-communist Czechoslovakia, was agreed by major political parties in December 1992. The current weak Czech Presidency is thus clearly the product of strong parties, not vice versa.

${ }^{51}$ Y. M. Brudny, 'The Dynamics of “'Democratic Russia', 1990-93', Post-Soviet Affairs, Vol. 9 (1993), pp. 141-70 and T. Grabowski, 'The Party That Never Was: The Rise and Fall of the Solidarity Citizens' Committees in Poland, East European Politics and Societies, Vol. 10 No. 2, (1996), pp. 214-45. 
${ }^{52}$ M. Hadjiisky, La fin du Forum civique et la naissance du Parti democratique civique (janvier 1990 - avril 1991) (Prague: Documents du travail du CEFRES No. 6, 1996).

${ }^{53}$ See 'Daniel Kroupa: Meziparlamentní klub demokratické pravice', Infórum, No. 44/90, 17 October 1990.

${ }^{54}$ Hadjiisky, La fin du Forum civique.

55 P. Havlík, Klaus \& ti druzí: Osobní inventura Petra Havlíka (Prague: Pallata, 1998), p. 25-6.

${ }^{56}$ Here I follow Hopkin's synthesis of the literature on party institutionalisation, adapting a rational choice framework. J. Hopkin , Party Formation and Democratic Transition in Spain, (Basingstoke: Macmillan, 1999). See also J. A. Aldrich, Why Parties? The Origin and Transformation of Political Parties in America, (Chicago: University of Chicago Press, 1995.

${ }^{57}$ P. Fiala, M. Mareš and P. Pšeja ‘The development of political parties and the party system' in Večerník and Matějů Ten Years of Rebuilding Capitalism, pp. 273-4, IVVM data cited p. 279.

${ }^{58}$ See A. Innes, 'The Breakup of Czechoslovakia: The Impact of Party Development on the Separation of the State', East European Politics and Societies, Vol. 11, No.3 (1997), pp. 393-435.

59 'Smlouva ODS a ČSSD' and 'Tolerační patent'

${ }^{60}$ V. Klaus, 'O politické odpovědnosti' and 'Pokus o interpretaci dnešní politické křižovatky’ in Od opoziční smlouvy k tolerančnímu patentu (Prague: Votobia, 2000), pp. 76-77 and 82-4. 
${ }^{61}$ See, for example, J. Macháček, 'Země dvou Mečiarů', Respekt, No 29/98 (1998), p.2 and J. Pehe, 'Mečiarismus najdeme i v Čechách', Mladá fronta dnes „30 September 1999.

${ }^{62}$ See B. Pečinka, 'Luxova velká politická hra', Lidové noviny, 7 December 1995, ‘Pokus o zesvětštění strany', Lidové noviny, 18 May 1996 and, ‘Česká CDU se nekoná', Respekt, No. 17, 20 - 26 April 1998, p. 3

${ }^{63}$ In addition to a governing Coalition Council established in September 1999, QuadCoalition also sought to establish a common electoral list, a electoral programme, 'Shadow Cabinet' and Prime Minister designate. The goals were formalised in an additional agreement in September 2000.

64 'Svatováclavské čtyřkoaliční dohoda' in Hamerský and Dimun, 10 let na straně svobody, pp. 226-7. Citation p. 227.

${ }^{65}$ Interview in Mladá fronta dnes, 14 July 1998 cited in P. Dimun, 'Komentár̆: Taková byla Čytrkoalice', Proglas, No. 2002/2 (2002), online edition.

${ }^{66}$ One third of the Czech Senate is re-elected every two years. After the November 2000 elections 39 of 81 Senators represented the Quad-Coalition. See 'ODS nýni stěži prosadí své zámězy’, Hospodařské noviny, 21 November 2000, p. 1.

${ }^{67}$ See V. Dvořáková, 'Civil Society in the Czech Republic' in P. Kopecký and C. Mudde (eds) Uncivil Society? Contentious Politics in Post-Communist Europe (London: Routledge, 2002), pp. 134-56.

${ }^{68}$ Dimun, 'Komentář: Taková byla Čytrkoalice'.

${ }^{69}$ The 'Coalition' received fewer votes than the total its two member party had received running separately in 1998 . See Hanley 'Europe and the Czech Parliamentary Elections of June 2002'.

70 See, for example, K. Williams, 'National Myths in the New Czech Liberalism' in 
G. Hosking and G. Schöpflin (eds.), Myths and Nationhood (London: Hurst, 1997), pp. 132-40 or P. Bugge, Czech Perceptions of the Perspective of EU Membership Havel vs. Klaus (Florence: European University Institute Working Paper RSC No. 2000/10, 2000 ) and S. Saxonberg, 'Václav Klaus: the Rise and Fall and Reemergence of a Charismatic Leader' East European Politics and Societies, Vol. 13, No. 2 (1999), pp. 391-418..

${ }^{71}$ T. Haughton, 'Facilitator and impeder: the institutional framework of Slovak politics during the premiership of Vladimír Mečiar', Slavonic and East European review, 2002, Vol.81, No.2, pp.267-290

72 D. Šrámek, 'Chceme vrátit lidem nadìjí', Fórum, No. 17/ (1991), p. 2.

73 'One man party?, Lidové noviny, 22 April 1991.

${ }^{74}$ Petr Nečas, an ODS Vice Chairman. 'Tvář s brýlemí je vedle ptáka cenným logem', Právo, 22 June 2002.

75 See Saxonberg,. 'Václav Klaus: the Rise and Fall and Re-emergence of a Charismatic Leader'.

${ }^{76}$ See also A. King, 'The Outsider as Political Leader: the case of Margaret Thatcher', British Journal of Political Science, Vol.32, No.3 (2002), pp.435-54

77 ‘Václav Klaus: Jakou roli bude hrát?’, Infórum, No. 44/90, 17 October 1990, p. 8. ${ }^{78}$ This paragraph summarises arguments discussed at more length in Hanley 'The New Right in the New Europe?'.

${ }^{79}$ Klaus did, however, make sporadic attempts to incorporate traditional Czech national symbols and myths into ODS ideology in the early 1990s. K. Williams, 'National Myths in the New Czech Liberalism'.

${ }^{80}$ Similarly, in stressing that political parties were not merely efficient, but were a 'standard' West European form of political organisation, ODS co-opted arguments 
first used by small historic parties of the left, indirectly drawing on pre-communist traditions of 'partyness'.

${ }^{81}$ See example of this assertion see ODS's internal analysis of its prospects after the June 2002 elections, M. Beneš, 'Volby PS PČR 2002 - analýza volební kampaně ODS

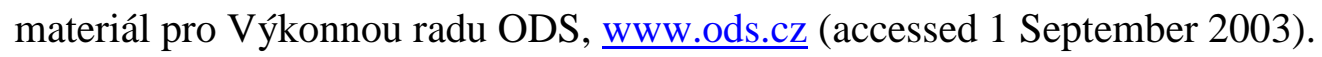

${ }^{82}$ See S. Hanley, 'From Neo-Liberalism to National Interests: Ideology, Strategy and Party Development in the Euroscepticism of the Czech Right', East European Politics and Societies, forthcoming 2004.

${ }^{83}$ Many scholars would find this parallel questionable. J. Zahradil, P. Plecitý, P Adrian and M. Bednář, Manifest českého eurorealismu, (ODS: Prague, April 2001) and published electronically at www.ods.cz (accessed 4 March 2004). 